\title{
Enhancing the performance of architectural design firms through addressing the gap of workforce skills in developing countries: a good-to-great approach
}

DOI 10.2478/otmcj-2018-0016

Received September 23, 2018; accepted December 17, 2018

\begin{abstract}
The aim of this research is to investigate the role of the good-to-great concept as an approach for enhancing the performance of architectural design firms (ADFs) through addressing the gap of workforce skills in developing countries. To achieve this aim, a research methodology was designed to accomplish four objectives: (1) building a comprehensive background about the topic through covering the nature of the construction industry, gap of workforce skills, previous approaches used to address this issue and the good-to-great concept; (2) presenting and analyzing two case studies to investigate the role of the good-togreat concept as an approach to fill the gap of workforce skills in organizations; (3) investigating the perception and application of the good-to-great concept for addressing the gap of workforce skills to enhance the performance of ADFs and (4) developing a framework to enhance the performance of ADFs through bridging the gap of workforce skills in ADFs using the good-to-great concept. Findings of this research showed that the issue of gap of workforce skills threatens all types of industries including construction industry. The demand of ADFs became greater than the supply of skilled employees which indicates a critical issue encountered by these firms. Thus, the good-to-great concept that has never been adopted in ADFs before is proposed as a novel approach to tackle this issue.
\end{abstract}

Keywords: gap of workforce skills, performance management, good-to-great concept, architectural design firms, developing countries

\footnotetext{
*Corresponding author: Ayman Ahmed Ezzat Othman, Architectural Engineering Department, Faculty of Engineering, The British University in Egypt (BUE), El Shorouk City, Cairo Suez Desert Road, Postal No. 11837, P.O. Box 43, Egypt; E-mail: ayman. othman@bue.edu.eg;

Dana Ashraf Sokkar, Architectural Engineering Department, Faculty of Engineering, The British University in Egypt (BUE), El Shorouk City, Cairo Suez Desert Road, Postal No. 11837, P.O. Box 43, Egypt;

E-mail: danaashraf94@hotmail.com
}

\section{Introduction}

Despite the rapid advances in technology and production management techniques, the construction industry remains one of the most people-reliant business sectors worldwide (Loosemore et al. 2003). Accordingly, the availability of skilled workforce is essential for achieving business objectives and enabling organizations operating in the construction industry to remain in market and competing for the future (Othman et al. 2004). In construction, there is a severe shortage of skilled professionals. This could be referred to the lack of training, poor motivation, inadequate human resource development, poor image of the construction industry, unethical behaviour and male-dominated culture (Knutt 1997; Cavill 1999). The construction industry generally and ADFs in particular experience a shortage of skilled workforce. Paauwe and Boon (2009) stated that gap of workforce skills has a crucial impact on the organization's performance, creativity, competitiveness and national economy. Therefore, this issue needs to be clearly understood and tackled as it is a reason for many business failure and non-competitiveness in the construction market. Gap of workforce skills is mainly divided into two types, namely shortage of skills and mismatch of skills. Shah and Burke (2005) stated that shortage of skills occurs when the demand for capable, willing and qualified employees who agree to work under the existing conditions is greater than their supply. Mismatch of skills is the gap between the skills that the employees possess and the skills needed for the available job, despite their agreement to work under any condition. Different approaches have been proposed to address this issue; however, the problem is still arising (Richardson 2007). The good-to-great concept is proposed as a novel approach for addressing the issue of gap of workforce skills. It is applied successfully in different fields of business; yet, it has never been applied within the construction industry and ADFs (Sokkar et al. 2017) which are characterized by less developed industrial base, low-income per capita and living standards, low education level and human development index, poor access to 
clean drinking water and sanitation facilities, high levels of pollution, inadequate access to family planning services and corruption at all government levels (Althor et al. 2016; Othman 2013). Towards learning from other industries, this research aimed to investigate the role of the good-to-great concept as a novel approach for enhancing the performance of ADFs through addressing the gap of workforce skills in developing countries.

\section{Literature review}

\subsection{An overview of the construction industry in developing countries}

The construction industry is one of the biggest industries worldwide. It plays a significant role towards the social and economic development of countries at national and international levels. The construction industry is mainly concerned with the development of projects and infrastructure facilities that fulfil the community needs and achieve the sustainable development objectives. In addition, it is linked to the maintenance and refurbishment of existing buildings. Moreover, it is one of the critical sectors in the economic development of any country due to its role in increasing country's gross domestic product, offering job opportunities and supporting other industries to excel (Organization for Economic Cooperation and Development, 2008). However, due to the unique nature of the construction industry in terms of being labour-intensive, multidisciplinary, highly fragmented business, relying highly on the skills and competencies of its workforce and slow adoption of new technology (Castagnino et al. 2014; Siriwardena et al. 2010), the productivity level of the construction industry is low when compared to other industries (Szymanski 2006; Oladinrin et al. 2012). Shortage of offering quality education and professional training programmes in developing countries is a major challenge that leads to lack of providing the construction industry with high-qualified human resources, which have the right skills that match with business demands. In addition, the lack of human resource development in management-related disciplines (e.g. project management, contract administration, leadership and communication) results in poor supply of experienced staff who can accept critical roles, which they are not prepared for (Georgieva 2012). Furthermore, there is an agreement between academics and professionals that academic institutions do not equip graduates with necessary skills required to meet the requirements of the construction industry (Nkado 2000; Chileshe and Haupt 2007; Rwelamila 2007) which highlights the need for human resource development. The labour market is as competitive as the commercial market, which means that attracting, rewarding, deploying and retaining people should be a primary focus within organizations. In the construction industry, this is particularly a complex issue as the workforce is itinerant and the industry relies on a wide spectrum of different skills, ranging from craft operative to support services and production management functions (Loosemore et al. 2003). To be effective, the construction industry and ADFs have to develop a strategy that responds to the labour market situation in which they operate.

\subsection{Gap of workforce skills in the construction industry}

Gap of workforce skills is an issue that threatens the success of any organization (Sitek 2012). Gap of workforce skills is the gap between what are the skills needed by the organization and what are the available skills (JP Morgan Chase and Co 2014). Some leaders understand the importance of bridging gap of workforce skills and consider it one of the top pressing concerns. Moreover, in both developed and developing countries, gap of workforce skills is a barrier to industries' growth, innovation and timely delivery of services and products, achieving the required quality standards and meeting economic and social requirements. Closing the gap of workforce skills has a direct connection with improving productivity, human resource development and economic growth (Aring 2012). The Considerate Constructors Scheme (2016) reported that the construction industry needs to recruit an average of 44,690 workers yearly. In addition, another study conducted by Barnes (2013) reported that $82 \%$ of managers believe that there is a remarkable gap of workforce skills in the construction industry. Mainly, there are two types of gap of workforce skills in the construction industry, namely skill shortage and mismatch of skills.

\subsubsection{Shortage of skills}

Shortage of skills mainly appears when there are no enough people with skills to meet the demand of construction industry. Shortage of skills makes it harder for a manager to find employees with suitable skills. There are two levels of shortage of skills: level 1, when the manager finds employees with "basic" skills and needs a "long" time to develop their skills; level 2, when the manager finds employees with "basic" skills and needs "short" 
time to develop their skills (Richardson 2007). However, in both levels, they are not readily available to use their skills which will hinder the organization from meeting deadlines and the industry requirements (Paauwe and Boon 2009; Richardson 2007). Shah and Burke (2005) stated that shortage of skills happens when the demand of construction industry for employees is greater than the supply of employees who are capable, willing and qualified to agree with working under the existing conditions of the job. Nonetheless, the Royal Institute of Chartered Surveyors (RICS) reported that $66 \%$ of ADFs are suffering from lack of staff, and it could grow over the next 5 years. This shortage is faced not only by the developing countries but also by the developed countries (Agency Central 2015).

\subsubsection{Mismatch of skills}

Mismatch of skills is the gap between the work skills that the employee possesses and what the organization demands. Mismatch of skills is when the employees have skills and do not use them but agree to work under any condition (Richardson 2007). Studies showed that sometimes people are becoming overqualified for their jobs. The greatest issue is that about $10 \%$ of managers do not realize that skills gap is an issue that affects their growth and competitiveness. Those managers are the most dangerous in the construction industry (Ryan 2016).

\subsection{Previous approach to bridge gap of workforce skills in the construction industry}

The global crisis of gap of workforce skills in the construction industry called for developing approaches and strategies to overcome this issue. The current research and best practice points to three remedy areas that organizations have to consider are as follows: first, developing a comprehensive understanding of the skills supply and demand through rigorous workforce planning; second, engaging in external partnerships to develop talent sources and finally, refining internal talent attraction and assessment practices to widen talent pools (Olson 2015). Results of a survey conducted by the Chartered Institute of Building (Barnes 2013) raised a number of recommendations to resolve the gap of workforce skills in the UK construction industry including the following: (1) placing construction higher on the political agenda, (2) offering employers further financial incentives to offer more internships and apprenticeships, (3) incentivizing careers in construction and sustainability amongst the younger generations, (4) creating more public sector projects, (5) cutting red tape and making it less burdensome for employers to recruit apprentices, (6) reducing tuition fees, (7) investing in innovation and (8) promoting and funding for further local enterprise partnerships. Despite the abovementioned approaches and effort done to bridge the gap of workforce skills in the construction industry, the problem still exists and these approaches lack some of the innovative methods included in the good-to-great concept.

\subsection{The good-to-great concept}

The good-to-great concept aims to implement different techniques to solve the problem of gap of workforce skills. The concept consists of seven main rules that if applied will turn a company from good to great.

\subsubsection{Leadership}

Mostly, people think that a leader is someone who manages and directs only. However, this is not true. The true leader motivates and inspires to reach the goal of the organization. There are five levels of leadership (Figure 1). Table 1 summarizes the different types and characteristics of leadership levels, which will enable leaders to adopt the appropriate level towards turning their organizations from good to great.

\subsubsection{First who then what}

Mostly, people think that building a great organization is based on two steps. The first one is to set a new vision, direction and strategy, whereas the second step is to select the right employees to achieve the organizational

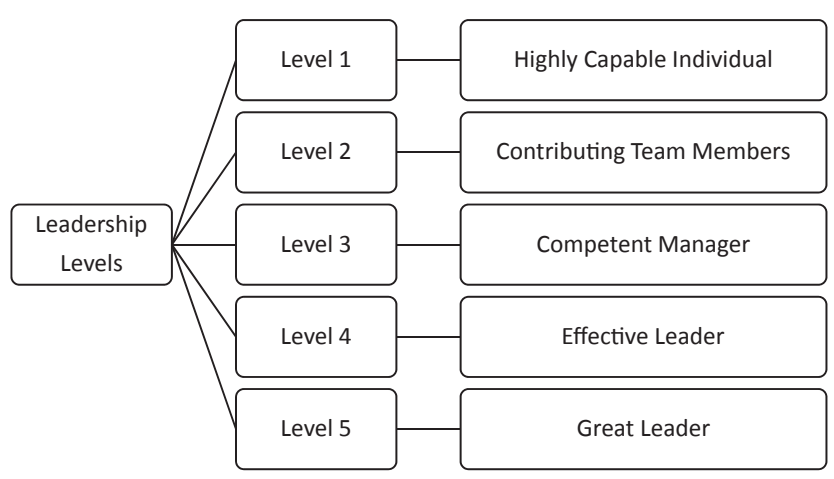

Fig. 1: Hierarchy of leadership levels (developed by the authors). 
Tab. 1: Types and characteristics of leadership levels.

\begin{tabular}{|c|c|}
\hline Type of leader & Characteristics \\
\hline $\begin{array}{l}\text { Level } 1 \text { : highly capable } \\
\text { individual }\end{array}$ & $\begin{array}{l}\text { The "highly capable individual" is a person who must be capable of making productive contribution using his/her } \\
\text { talent, knowledge, skills and good work habits (Collins 2001) }\end{array}$ \\
\hline $\begin{array}{l}\text { Level 2: contributing } \\
\text { team members }\end{array}$ & $\begin{array}{l}\text { In this level, the leader must be able to work effectively within teams to achieve the group objectives (Collins 2001). } \\
\text { Level } 2 \text { leadership is not far from level } 1 \text {, instead, the scope of contributions is slowly getting wider. Level } 1 \text { leader } \\
\text { must be able to make productive contributions, whereas level } 2 \text { leader must be able to make productive contribu- } \\
\text { tions within a group and to achieve the group objectives }\end{array}$ \\
\hline $\begin{array}{l}\text { Level 3: competent } \\
\text { manager }\end{array}$ & $\begin{array}{l}\text { A "competent manager" must be able to manage and organize people and resources to work effectively to reach the } \\
\text { organization goal (Collins 2001). In this level, a competent manager must be more matured and must understand } \\
\text { that time is not money, but time is the measure of work done by the organization (Bassett 2015). Moreover, he/she } \\
\text { must know that the company does demand not only for materials but also for skilled labour }\end{array}$ \\
\hline $\begin{array}{l}\text { Level 4: effective } \\
\text { leader }\end{array}$ & $\begin{array}{l}\text { In this level, the leader must get the organization with high performance standards (Collins 2001). The effective } \\
\text { leader must have a strong personality and expert communication skills, know what the organization wants and } \\
\text { know how to achieve it. The effective leader must be honest and trust worthy. He must motivate and encourage } \\
\text { employees to reach the organization's desired mission (Ulrich and Smallwood 2012) }\end{array}$ \\
\hline $\begin{array}{l}\text { Level } 5 \text { : the great } \\
\text { leader }\end{array}$ & $\begin{array}{l}\text { In this level, the leader must develop all the levels of the leadership pyramid. He/she must be the one who builds } \\
\text { a great company through a paradox combination of "humility" and "professional will". Level } 5 \text { leaders usually put } \\
\text { their egos away and work for making an organization great (Collins 2001) }\end{array}$ \\
\hline
\end{tabular}

objectives. However, the leaders who are able to build a great organization do not start with the direction. They start with getting the right people in and the wrong people out. Then, they figure out where they need to go and what is going to be the right direction. Good-togreat leaders figure out three important rules they have to follow. First, when "who" comes before "what", adapting with different and changing situations will be easy. In contradiction with putting "what" before "who", if an organization is moving in the wrong direction with the wrong people there will be a real problem. Second, when the right people are selected, there will not be a problem in motivating them. Right people do not need to be managed tightly. However, in the right place, they have an inner drive that makes them self-motivated. Finally, when the organization has the wrong people, it will not matter if they know the right direction or not. No organization will be great without great people. In contrast, most organizations fear employing the best managers. They know that they might leave the organizations and work in higher positions any time which will cause a blow to their organizations. They work with a "weak generals-strong lieutenants" strategy. They believe that weak employees will always stick around. The idea of selecting the right people first is the perceiver and the hardest to do. Unlike level 5, great leaders who have the right people first then figure out the right path, level 4 leaders can hardly build a great organization, because they just need a good team to help them in implementing their ideas. Moreover, when they leave, the organization fails. They use "what” then "who" concept (Collins 2001).

\section{Compensation}

When people are put in right places, they work because they have an inner power to build the organization, not because they get paid for working. Right people deliver the best result regardless of the compensation. Compensation is important but when people work with passion they will produce more than people who earn more money but work in an environment they do not feel passionate about (Collins 2001).

\section{Rigorous vs. ruthless}

Rigorous and ruthless are two words totally far away from each other. When putting the right people in the right place, leaders must be rigorous. It is never pleasing to see people losing their jobs. Ruthless means hacking and cutting employees, especially in difficult times, or wants only to fire people without any thoughtful consideration. A rigorous leader focuses on consistently applying exacting standards at all times and at all levels. Being ruthless means firing people or making them worry about their positions or that they could be easily replaced. Great leaders are never ruthless. They want employees to concentrate on working not their positions (Collins 2001).

\subsubsection{Confront the brutal facts, yet never lose faith}

Although, good-to-great organizations do have a track record of their performance, they make more good decisions than bad ones. However, good decisions cannot be taken with confronting the facts of the organizations. 
Great organizations refine greatness path with facing the brutal facts. Great leaders have to confront the brutal facts without demotivating people. The leader must not hold false hope to keep people motivated. However, if the organization gets the right people from the start, they will work together to change the situation to the better. They will never get demotivated because of a bad situation. Instead, they will give all their passion and energy to solve the issue after facing the brutal facts. They will never lose faith in making the organization great. Great leaders follow four rules to face the reality of the issue, yet never lose faith.

- First, "lead with question, not answers". This helps the leader to have a clear vision, because they hear from all people working within the organizations, help motivating employees and make them more loyal to the organization.

- Second, engaging in dialogues, debates, but not coercion. Some meetings have some problems, as people have different opinions and visions. This helps the leader more to reach a decision that is good for all people.

- Third, "conducting autopsies, without blame". This means that the environment of the organization will be where the truth is heard. Thus, there will be no one to blame.

- Fourth, building "red flag" mechanisms. Great companies have the red flag to have better track of information and retain faith that has to prevail in the end, regardless of the difficulties and at the same time confront the most brutal facts of current reality whatever it might be.

\subsubsection{The hedgehog concept}

The fox knows many things; however, the hedgehog knows only one thing. The fox stands every day and waits for the hedgehog to hunt him, whereas the little hedgehog senses the danger and rolls into a little ball. This story happens every day, and the fox never catches the hedgehog and never learns. Based upon this concept, leaders are divided into two categories: the foxes and the hedgehogs. Foxes pursue different ends at the same time and see complexity in every situation. On the other hand, hedgehogs simplify complex situations into one single organized idea that guides through everything. The hedgehog does not bother with the complexity of the world. This does not mean that he does not ignore things that are not complex, but he ignores everything and concentrates on the important things only. Good-to-great leaders who follow the hedgehog rules concentrate on the essential things and ignore the others and simplify the situation into a clear guide for all the people to understand.

\subsubsection{A culture of discipline}

Not all companies that started great remained great. At the beginning, people felt that they were working with passion and ended up feeling bored of the work just applying rules. There is no place for creativity and passion. This is the difference between level 4 and level 5 leaders. This happens due to the lack of measuring the process of the organization plans. However, level 5 managers always measure the plans and see when there is a change needed and they change. Changing a plan is a very hard mission, but if the right people are in the right place from the beginning it will not be difficult. Leaders must have an environment that provides employees with freedom and responsibility and clear constraints. Then, workers will work hardly by themselves.

\subsubsection{Technology accelerators}

The technology trap is that people think that "new technology will change everything”. Good-to-great leaders use technology as an accelerator not as a creator. When technology is used as an accelerator only, then the change will be easy. Technology must never be the pioneer of any organization. Moreover, good-to-great leaders connect technology directly with the hedgehog concept. If employees can perform best with technology, are able to be pioneers of an application and are passionate about it as well as the technology can drive the economic indicators of the organization, then the decision must be to use this application. Otherwise, the application must be eliminated from all the plans. Nevertheless, good-to-great leaders never mention that technology is the main asset of any organization.

\subsubsection{The flywheel and the doom loop}

The flywheel simply means that every positive action done will move the organization one step forward. Each action equals a turn. Good-to-great leaders believe that there are no miracles and that the success of an organization is counted from the first step. However, some organizations enter the doom loop. This happens when they confuse between working to achieve a step forward and working 
without having a plan. Leaders in this phase motivate the employees to push them one step forward and to feel appreciated to continue. Moreover, they never blame an external factor for any failure that happens to the industry.

\subsection{The relationship between gap of workforce skills, good-to-great concept and performance improvement}

Gap of workforce skills is an issue that most organizations suffer from especially ADFs. There are two types of gap of workforce skills, namely shortage of skills and mismatch of skills. Good-to-great concept has seven sub-concepts that work to address the issue of gap of workforce skills. Any industry begins with a leader who is the main key of any improvement. When the leaders have the level 5 skills, then he/she has the ability to choose the right employees to fill the right places. When the right people are put in the right places, the gap of workforce skills is necessarily solved. Leaders must understand that if the job is empty and there is a doubt about the skills of the employees, it is better to leave this place empty. Nonetheless, leaders must be similar to hedgehogs to have a clear plan to guide all people. They must also know what are the drivers for all employees and what are they passionate about. Moreover, they must understand that technology is just an accelerator not the pioneer of the industry. Finally, leaders must follow the flywheel and keep moving the organization forward. Adopting such approach will enable ADFs to improve their performance and maintain their competitiveness in market.

\subsection{Challenges and benefits of closing gap of workforce skills}

Gap of workforce skills poses the greatest threat to the future of the construction industry worldwide. In addition, it continues as the demand for construction work increases, which puts pressure on the construction industry which is struggling to meet increasing demand for its services (Creamer 2007). Organizations acting in the construction industry are reluctant to invest in closing their gap of workforce skillss as the cost is tangible and clearly visible, whilst the benefits are often intangible and build up only over time. Moreover, organizations are often unable to reap the benefits of their investment if the newly upskilled employees leave the company or if suppliers turn towards competitors. However, closing the gap of workforce skills will impact positively on the workforcedevelopment, thevaluechain, and thecommunity (European Development Finance Institutions 2016).

\subsubsection{Workforce development}

Bridging the gap of workforce skills plays a significant role towards increasing the productivity of employees with higher quality. In addition, it helps increase the ability to adopt new production technologies and higher innovation levels. Moreover, closing gap of workforce skills provides organizations with larger internal talent pool for management, larger pool of prospective workers, improved work safety, increased employee satisfaction and motivation as well as higher retention. Furthermore, it provides organizations with easier access to markets, reduces operational risk, enhances company reputation and improves government and community relations.

\subsubsection{Value chain development}

Closing the gap of workforce skills and developing skills of the value chain help small and medium enterprises (SMEs) to enhance their productivity and expand their business. Through training its suppliers or distributors, organizations will be able to achieve timeliness sustainable improvements, reliability of supplies and higher sales of its products. Furthermore, this will help reduce input costs, enhance organization reputation, increase bargaining power and reduce risk through improved work safety.

\subsubsection{Community development}

By undertaking initiatives to bridge the gap of workforce skills, communities will benefit through building better community relations and securing of social license to operate. In addition, it will improve governmental relations, enhance organization reputation and ensure longterm supply of employees.

\section{Research objectives and methodology}

To achieve the abovementioned aim, a research methodology consisted of literature review, case studies and survey questionnaire was designed to achieve the following four objectives: 
- Literature was used to investigate the nature of the construction industry, gap of workforce skills, previous approaches adopted to address gap of workforce skills and good-to-great concept.

- Two case studies were presented and analyzed to investigate the role of the good-to-great concept towards filling the gap of workforce skills in organizations.

- A survey questionnaire was conducted with a reprehensive sample of $44 \mathrm{ADFs}$ in Egypt to investigate their perception and application of the good-to-great concept as an approach for enhancing the performance of ADFs through filling gap of workforce skills.

- A framework was developed to enhance the performance of ADFs through bridging gap of workforce skills using the good-to-great concept.

\section{Case studies}

\subsection{Background and selection criteria}

This section presents and analyzes two case studies of organizations that adopted different approaches to fill gap of workforce skills. Although some of these approaches failed to address gap of workforce skills, some succeeded. These approaches are analyzed in comparison with the good-to-great concept. The selection criteria for case studies are initially based on ADFs operating in developing countries and adopt the good-to-great concept. As this concept was not applied in the construction industry before and in ADFs in particular worldwide, the present cases are selected from other industries operating in USA. However, learned lessons will be beneficial for application in ADFs in developing countries.

\subsubsection{Case study 1: Bethlehem Steel Company, Pennsylvania, USA}

Bethlehem Steel Company was built in 1886, opened in 1890 and closed in 1995. Bethlehem was the second largest steel producer in USA. However, it decayed for 22 years due to the world bankrupt (Bethlehem-Steel-Mill 2010). The company suffered from gap of workforce skills in terms of limited skilled labours, poor future planning and lack of management skills. To overcome these issues, the company adopted three approaches, namely (1) increasing benefits (i.e. paying school fees and renovating executive clubs), (2) changing office design to increase employees' productivity and (3) replacing people with machines to accelerate the production of mini-mill steel in the company. Despite these approaches, the issue of gap of workforce skills was not resolved due to a number of reasons such as lack of management systems in engaging employees in the decision-making process, lack of leadership skills in aligning the organization's need with the employees' needs, inappropriate training of employees to use the new technology, lack of future planning and developing red flag mechanism to reduce the rate of facing fatal issues.

\subsubsection{Case study 2: Nucor Corporation, USA}

Nucor Corporation is one of the contributors of the goodto-great concept. The company was established in 1897 by Ransom E. Olds as Motor Vehicle Company (later, known as Oldsmobile). In 1905, Olds left Oldsmobile and established REO Motor Car Company. Despite the popularity of REO's products, they were not profitable, and the company filed for bankruptcy protection in 1938. In 1954, REO sold its entire manufacturing operations and began a tiny nuclear services company called "Nuclear Corporation of America Inc.", and relocated to the Empire State Building in New York City. In 1962, Nucor Corporation made three important moves that changed the company; first, they changed the company strategy to be part of the American steel industry, second, they acquired alliance with another company called "Vulcraft" that produces girders and steel joists and, finally, they hired "Ken Iverson", one of the 11 great leaders worldwide who succeeded to turn the company from bankruptcy to be a great company (Nucor Corporation 2016). The company encountered the issue of limited skilled labours. To resolve this issue, the company employed two techniques, namely changing the place of the company and applying the seven good-to-great concepts. The rationale of changing the place of the company to Utah was to be near the farmers who wanted to work and had the ability to perform the work by the needed skills and work with passion. For the second technique, the leader was able to turn the company from being good to being great by applying the seven concepts of success. Moreover, he was able to make it the largest steel production company. Through applying these concepts, the leader was able to look in the mirror to review things that went wrong and remind himself of his responsibility and look outside the window when things went well and look at the great people who made that success. In addition, he was able to attract hard workers through paying them more than any other steel companies and aligned compensation to productivity. Nucor Corporation did not encourage lazy workers to work more, but the environment gave them the choice either 
Tab. 2: Comparison of case studies against the good-to-great concept.

No. Case study

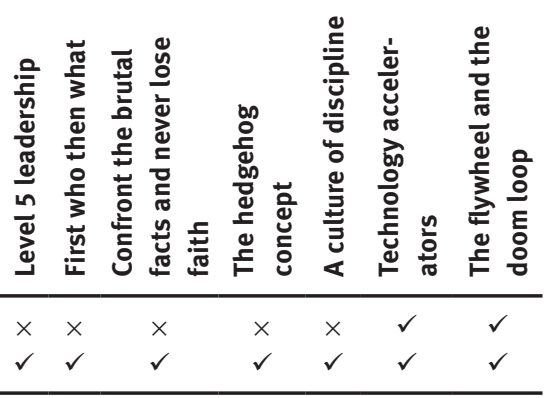

to leave or to be productive. Moreover, through creating a performance culture and making long-term plan for new technology, the company succeeded to be the low-cost steel producer in USA. Furthermore, the leader succeeded to align the company's needs with the needs of the employees and translate this simple concept into a discipline action across the company. Finally, Nucor Corporation had contributed more than 70 million dollars to education and scholarships for team development and keeping the company in the flywheel mode (Collins 2001; Nucor Corporation 2016). Table 2 summarizes the comparison between the two case studies against the good-to-great concept.

\section{Data analysis}

\subsection{Overview and survey questionnaire design}

This section summarizes the results of a field study carried out through a survey questionnaire with a representative sample of 44 Egyptian ADFs to investigate their perception and application of the good-to-great concept as an approach for improving the performance of ADFs through bridging the gap of workforce skills in developing countries. The survey questionnaire consisted of three sections. The first section was designed to collect information about the respondents' specialty, experience, position and contacts. The second section was designed to investigate the awareness, types, causes and impacts of skills gap and actions adopted to overcome this issue in ADFs. The last section was dedicated to examine the perception and application of the good-togreat concept as an approach for bridging the skills gap in ADFs. In the survey questionnaire, two types of questions were used: first, close-ended questions, in which the respondents are allowed to select a single response of yes/no or rate the response on the Likert scale from 1 to 5; second, open-ended questions, in which respondents are given the opportunity to express their thoughts. Open-ended questions allow unanticipated findings to be explored and permitted richness of details and self-expression (Baker 1994).

\subsection{Sampling and response rate}

To select a representative and non-biased sample to answer the survey questionnaire, the list of all ADFs registered in the Egyptian Engineers Syndicate (EES 2018) was obtained resulting in a population of 44 firms. To calculate the sample size, the next two equations were applied (FluidSurveys Team 2014). In this research, the confidence level chosen is $95 \%$, and the margin of error is $5 \%$. The confidence level score corresponding to the confidence level of $95 \%$ is 1.96 .

$$
\begin{aligned}
\text { Sample size calculation }=\frac{\text { Distrubution of } 50 \%}{\left[\frac{\text { Margin of error } \%}{\text { Confidence level score }}\right]^{2}} \\
\text { True sample }=\frac{\text { Sample size } \times \text { population }}{\text { Sample size }+ \text { population }-1} \\
\text { Sample size }=\frac{0.5 \times(1-0.5)}{\left[\frac{0.05}{1.96}\right]^{2}}=384.16 \\
\text { True sample }=\frac{384.16 \times 44}{384.16+44-1}=39.57 \sim 40
\end{aligned}
$$

However, since the true sample size of $40 \mathrm{ADFs}$ is only different from the population size in this case by 4 , the whole population was considered the sample size for the survey questionnaire. A pilot study of the survey was tested with colleagues to determine its effectiveness and problems. They were asked to answer the questions as if they were received from someone unknown and go through the questionnaire again to point out any problem they noted with questions. After going over the responses of the preliminary test and making changes, the questionnaire was ready for formal testing (Baker 1994; Czaja and Blair 1996). A copy of the survey questionnaire was sent electronically to all the $44 \mathrm{ADFs}$ by contacting them at first through their formal email addresses or directly by calling them depending on the available contact information. Out of 44 ADFs participated in the 
survey questionnaire, only 29 firms responded representing $69 \%$ that supports the research findings and recommendations. Results of the survey questionnaire revealed the following.

All respondents showed their awareness of the issue of gap of workforce skills and its impact on their organizations by varying degrees. Thirty-one percent of respondents rated their awareness as 5/5,31\% rated their awareness as $4 / 5$ and $38 \%$ rated their awareness as $3 / 5$. The measure of central tendency highlighted a good typical value for mean (3.86/5), median (4/5) and mode (4/5) which reflects the quality of collected data. In addition, the measure of dispersion highlighted the homogeneity of collected data via variance (0.47) and standard deviation (0.69). These results reflect the maturity of ADFs to confirm their awareness of this critical issue.

1) $89.3 \%$ of respondents stated that immediate actions should be taken by their ADFs to overcome the consequences of gap of workforce skills.

2) Thirty-nine percent of respondents stated that their firms suffer from shortage of skills, $22 \%$ suffer from mismatch of skills and 39\% of respondents stated that their firms suffer from both types of gap of workforce skills.

3) Thirty-six percent of respondents stated that complete reliance on technology is an important factor of causing gap of workforce skills. This is because complete reliance on technology affects innovation and creativity especially in the architectural field. Skilled employees are needed to use technology to facilitate their work as technology cannot perform on its own. Twenty-one percent of respondents stated that hiring overqualified employees is another factor of increasing gap of workforce skills, especially mismatch of skills. Fifty-four percent of respondents ensured that continuous changing in organizational goals due to market economic conditions leads to lack of planning and causes increased gap of workforce skills. Twenty-nine percent of respondents stated that other factors can cause gap of workforce skills such as the unwillingness of ADFs to pay sufficiently for the skills they need, failing of the educational system to grow a skilled workforce, lack of candidates' willingness to move to where the jobs are located and insufficient governmental efforts to support the skilled labour markets (Figure 2).

4) There are a number of approaches adopted by ADFs to bridge gap of workforce skills in Egypt. Eighty-two percent of respondents apply training programmes, $68 \%$ of respondents increase the employment benefits and compensation and 39\% of respondents implement new technologies. About 29\% of respondents use flexible management systems such as outsourcing, talent management and lean management.

5) All respondents showed their awareness of the goodto-great concept by varying degrees. Eleven percent of respondents rated their awareness as $5 / 5$, and $11 \%$ rated their awareness as 4/5. On the other hand, 28\% rated their awareness as $3 / 5$ and $50 \%$ responded that they are not aware of the concept.

6) $\mathrm{ADF}$ that responded to the survey questionnaire showed that they apply the good-to-great concept in varying degree as shown in Figure 3. About $43 \%$ of respondents referred that they do not apply the goodto-great concept due to their unawareness of the concept or the lack of senior management support. The second highest percentage of ADFs showed that they use technology accelerator to improve their performance, which could be considered as best practice.

7) Respondents stated that they would start applying the good-to-great concept by using different methods: about 30\% stated that they will change the leadership system, $65 \%$ will have the right employees in and the wrong ones out, 70\% will make a clear future map, $65 \%$ will combine ethics with the work system, $61 \%$ will define their passion and their economic engine, $26 \%$ will use technology as a second priority and $4 \%$ will use other methods.

8) About $11 \%$ of respondents stated that there is no need to develop a framework to implement the goodto-great concept, where $89 \%$ stated that a framework is needed.

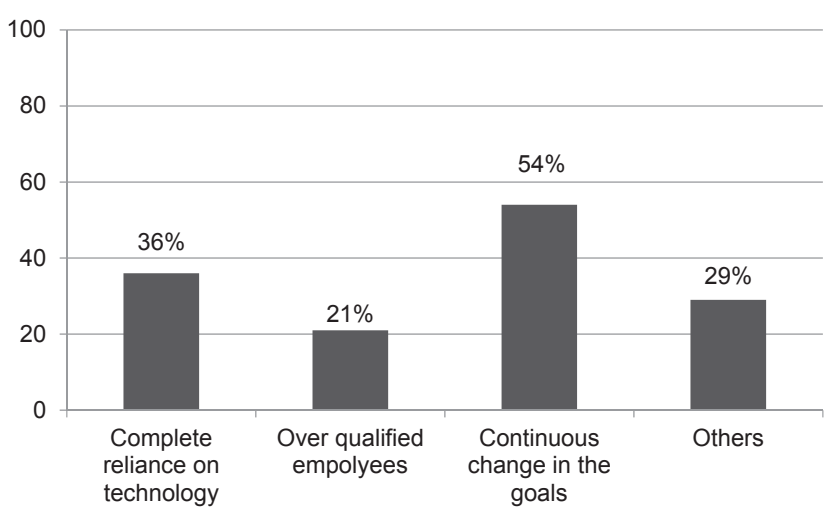

Fig. 2: Factors causing gap of workforce skills in ADFs.

Abbreviation: ADFs, architectural design firms. 


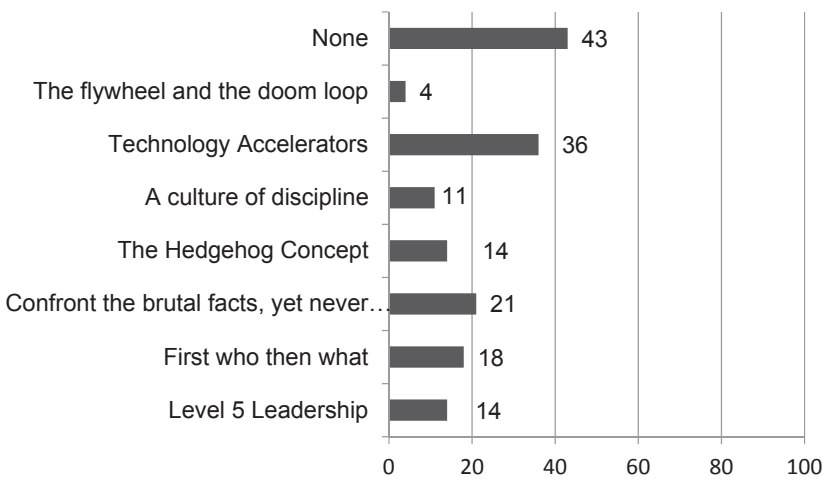

Fig. 3: Averages regarding the good-to-great concept in ADFs. Abbreviation: ADFs, architectural design firms.

\section{Good-to-great concept implementation framework}

\subsection{Definition and importance}

A framework is simply an arrangement of series of concepts, tools and approaches needed to be reached into a designed structure to complete a specific process (Othman and Mia 2008). In addition, it is a series of actions needed to achieve a specific objective (Othman and Sirbadhoo 2009). The good-to-great concept implementation framework (hereinafter referred as G2GIF or the framework) is a proposed framework describes the steps and procedures needed to investigate and address the issue of gap of workforce skills in ADFs through implementing the good-to-great concept. The need for the framework emerges from the necessity of establishing organized procedures that enable ADFs in developing countries to integrate the goodto-great concept to address and bridge the gap of workforce skills issue as an approach for improving their performance.

\subsection{Aim and steps of the framework}

The framework aims to improve the performance of ADFs through bridging the gap of workforce skills of ADFs in developing countries. This aim will be achieved through accomplishing the following steps.

- Diagnosing current challenge of gap of workforce skills.

- Identifying the good-to-great concept for implementation

- Planning and implementing the good-to-great concept

- Monitoring and evaluating obtained results.

- Implementing corrective actions and closing out.

\subsection{The description of the framework}

Table 3 describes the objectives, activities, tools and techniques, involved personnel and needed resources as well as the output of every step.

\subsection{Benefits and limitations of the good-to- great framework}

Based on the authors' deduction, the framework has a direct impact on enhancing the performance of ADFs through bridging the issue of gap of workforce skills. In addition, the framework provides a new innovative systematic approach that helps improve the attitude of employees working within ADFs as they address the gap of workforce skills in a way that was not adopted before in ADFs. This framework will help in adopting new ways for solving major issues in ADFs. On the other hand, the effective application of the framework depends to a large extent on the encouragement of the top management in ADFS to bridge the gap of workforce skills in developing countries. If the top management does not have the desire and tends not to use the framework, then its adoption will be limited. The application of the framework is a longterm strategy to fill the gap of workforce skills in ADFs, and within the current culture in the construction industry where performance is almost calculated in monetary terms and limited attention has been paid for the issue of gap of workforce skills; this framework might not be welcomed by some sectors of the industry. The benefits of the framework should be clearly presented to the top management of ADFs to get them convinced with the role, which the framework could play in bridging the gap of workforce skills of ADFs in developing countries. This will increase the opportunities for adopting the framework. The timeline for implementation as indicated is a long-term commitment. It is important to note that, depending on changing the attitudes and perceptions of managers who shape the missions and visions of ADFs, the timeline for implementing the framework may vary accordingly.

\section{Conclusions and recommendations}

Gap of workforce skills is one of the greatest challenges faced by countries worldwide, especially developing countries. The complexity of the problem affects the national economy and hinders governments from achieving their 
Tab. 3: Detailed description of the framework.

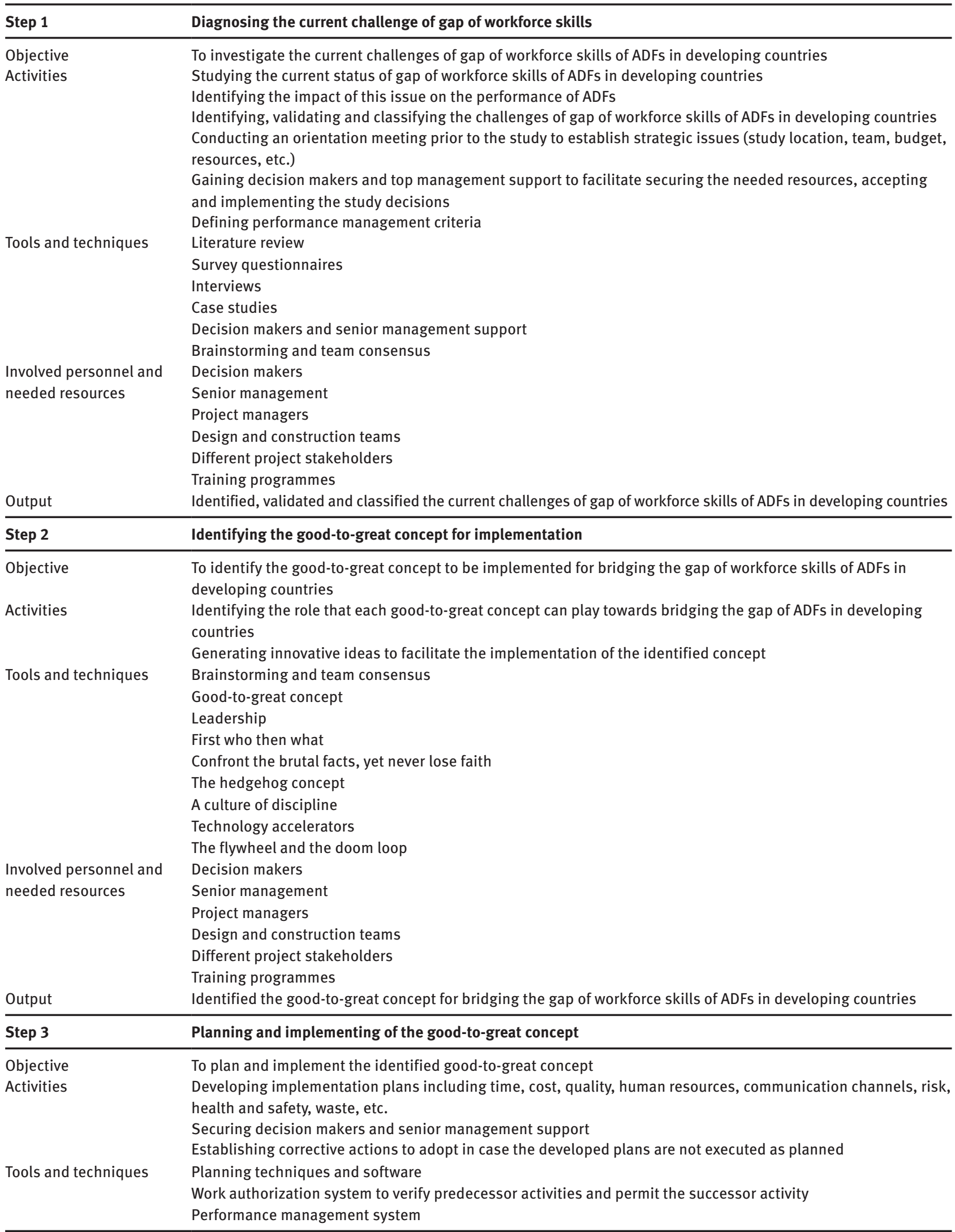


Tab. 3: Continued.

\begin{tabular}{|c|c|}
\hline Step 3 & Planning and implementing of the good-to-great concept \\
\hline $\begin{array}{l}\text { Involved personnel and } \\
\text { needed resources }\end{array}$ & $\begin{array}{l}\text { Decision makers } \\
\text { Senior management } \\
\text { Project managers } \\
\text { Design and construction teams } \\
\text { Different project stakeholders } \\
\text { Training programmes } \\
\text { Planning and implementation plans }\end{array}$ \\
\hline Step 4 & Monitoring and evaluating the obtained results \\
\hline $\begin{array}{l}\text { Objective } \\
\text { Activities }\end{array}$ & $\begin{array}{l}\text { To monitor and evaluate the results obtained from the planning and implementation step } \\
\text { Measuring the results against the performance measures developed earlier } \\
\text { Identifying and evaluating the causes of failure and issues that resulted in deviation from the original plans }\end{array}$ \\
\hline Tools and techniques & $\begin{array}{l}\text { Change control procedures } \\
\text { Financial control procedures } \\
\text { Issue and defect management procedures defining issue and defect controls, issue and defect } \\
\text { Identification and resolution and action item tracking }\end{array}$ \\
\hline $\begin{array}{l}\text { Involved personnel and } \\
\text { needed resources }\end{array}$ & $\begin{array}{l}\text { Decision makers } \\
\text { Senior management } \\
\text { Project managers } \\
\text { Design and construction teams } \\
\text { Different project stakeholders } \\
\text { Training programmes }\end{array}$ \\
\hline Output & $\begin{array}{l}\text { Action plans and corrective actions to overcome the issues raised during the implementation of the good- } \\
\text { to-great concept }\end{array}$ \\
\hline Step 5 & Implementing corrective actions and closing out \\
\hline $\begin{array}{l}\text { Objective } \\
\text { Activities }\end{array}$ & $\begin{array}{l}\text { To implement the corrective actions developed during the previous step and close out projects } \\
\text { Implementing corrective actions } \\
\text { Documenting learned lessons and sharing them with decision makers, design and construction teams and } \\
\text { related project stakeholders } \\
\text { Obtaining acceptance of senior management of ADFs to formally close the project or phase } \\
\text { Performing team members' assessment and releasing project resources }\end{array}$ \\
\hline Tools and techniques & $\begin{array}{l}\text { Expert judgement } \\
\text { Reporting } \\
\text { Knowledge management }\end{array}$ \\
\hline $\begin{array}{l}\text { Involved personnel and } \\
\text { needed resources }\end{array}$ & $\begin{array}{l}\text { Decision makers } \\
\text { Senior management } \\
\text { Project managers } \\
\text { Design and construction teams } \\
\text { Different project stakeholders } \\
\text { Training programmes }\end{array}$ \\
\hline Output & Successfully bridging the gap of workforce skills of ADFs in developing countries \\
\hline
\end{tabular}

plans for sustainable development. Due to its nature, the construction industry generally and ADFs in particular suffer from skills gap that affects their productivity, competitiveness and human development. Despite the different approaches and strategies adopted to bridge the skills gap in construction, the problem still exists and these approaches lack some of the innovative methods included in the good-to-great concept. This concept aims to implement different techniques to solve the problem of gap of workforce skills. The concept consists of seven main rules that if applied will turn a company from good to great. Having reviewed literature and case studies and keeping in mind the results of the survey questionnaire, the research comes to the following recommendations.

- The issue of gap of workforce skills must be properly identified and clearly understood. This will enable ADFs to bridge the skills gap which will impact positively on improving their performance and sustaining their competiveness and market share.

- Providing the Senior Management in ADFs with the tangible benefits of the good-to-great concept towards bridging the shortage of skills gap, will facilitate 
offering the needed resources and allowing the time required for ensuring successful implementation.

- Testing and validating the proposed framework to ensure that it could provide the benefits advocated (through surveying of opinions and stands of government authorities and project stakeholders, etc.).

- Seeking the support of the governmental authorities responsible for workforce development to increase their willingness to adopt and implement the good-to-great concept as an approach for bridging the gap of workforce skills in the construction industry.

\section{References}

Agency Central. (2015). Is There A Skill Shortage in the Construction Industry? Available at http://www.agencycentral.co.uk/ articles/2015-11/skill-shortages-in-construction-industry.htm on 15 September, 2018.

Althor, G., Watson, J. E., \& Fuller, R. A. (2016). Global mismatch between greenhouse gas emissions and the burden of climate change. Scientific Reports, 6(1), p. 20281. doi: 10.1038/ srep20281.

Aring, M. (2012). Skills Gaps Throughout the World: An Analysis for UNESCO. Global Monitoring, Report 2012. Available at http:// unesdoc.unesco.org/images/0021/002178/217874e.pdf on 15 September, 2018.

Baker, T. L. (1994). Doing Social Research, 2nd edn. McGraw-Hill, New York.

Barnes, D. (2013). A Report Exploring Skills in the UK Construction Industry. The Chartered Institute of Building (CIOB). Available at https://www.ciob.org/sites/default/files/Skills\%20 Report\%202013_0.pdf on 15 September, 2018.

Bassett, G. (2015). What Does It Take to Become a Competent Manager? American Management Association. Available at https://playbook.amanet.org/what-does-it-take-to-become-acompetent-manager/ on 15 September, 2018.

Bethlehem-Steel-Mill. (2010). Available at http://opacity.us/site87_ bethlehem_steel_mill.htm on 15 September, 2018.

Castagnino, S., Gerbert, P., \& Rothballer, C. (2014). What's the Future of the Construction Industry? Available at https://www. weforum.org/agenda/2016/04/building-in-the-fourth-industrial-revolution/ on 15 September, 2018.

Cavill, N (1999). Where have all the young QSs gone? Building, 26 March, 1999.

Chileshe, N., \& Haupt, T. C. (2007). Industry and academia perceptions of construction management education - the case of South Africa. The Journal for Education in the Built Environment, 2(2), pp. 85-114.

Collins, J. (2001). Good to Great: Why Some Companies Make the Leap and Others Don't, 1st edn. Harper Business. ISBN: 978-0066620992.

Considerate Constructors Scheme. (2016). CITB highlights workforce skills gap as the industry grows. Available at https://www. ccscheme.org.uk/citb-highlights-skills-gap-as-the-industrygrows/ on 15 September, 2018.
Creamer, T. (2007). Creating losing projects. Engineering News Online, 16 November, 2007.

Czaja, R., \& Blair, J. (1996). Designing Surveys: A Guide to Decisions and Procedures. Pine Forge Press, Thousand Oaks, CA.

EES (2018). Egyptian Engineers Syndicate. [Online]. Available from: http://eea.org.eg/ (Accessed 12 October 2018).

European Development Finance Institutions. (2016). Bridging the Skills Gaps in Developing Countries: A Practical Guide for Private-Sector Companies. European Development Finance Institutions, ASBL, Brussels, Belgium. Available at http:// www.skillsforemployment.org/KSP/en/Details/?dn=WCMSTEST4_168258 on 15 September, 2018.

FluidSurveys Team. (2014). Calculating the Right Survey Sample Size. Available at http://fluidsurveys.com/university/calculating-right-survey-sample-size/ on 2 December, 2018.

Georgieva, T. M. (2012). Research infrastructure megaproject (RIMPS) management in an ecosystem perspective: Literature review. Organisation, Technology and Management in Construction: International Journal, 3(2), pp. 333-347.

JP Morgan Chase and Co. (2014). Closing the Skills Gap Preparing: New Yorkers for high-growth, High-Demand, Middle-Skill Jobs. Available at https://www.jpmorganchase.com/ corporate/Corporate-Responsibility/document/54841-JPMCGAP-REP-AW6.pdf on 15 September, 2018.

Knutt, E. (1997). How big is the trade gap? Building, 2 May, 16-18. Loosemore, M., Dainty, A., \& Lingard, H. (2003). Human Resource Management In Construction Projects: Strategic And Operational Approaches. Routledge. ISBN: 978-0415261647.

Nkado, R. N. (2000). Competencies of professionals quantity surveyors in a developing economy. In: 2nd International Conference on Construction in Developing Countries: Challenges Facing the Construction Industry in Developing Countries, Gaborone, Botswana, 15-17 November, 2000.

Nucor Corporation. (2016). Making Steel the New Fashioned Way. Available at http://www.nucor.com/ on 15 September, 2018.

Oladinrin, T., Ogunsemi, D., \& Aje, I. (2012). Role of construction sector in economic growth: Empirical evidence from Nigeria. FUTY Journal of the Environment, 7(1), pp. 50-60.

Olson, M. P. (2015). A multilateral approach to bridging the global skills gap. Cornell HR Review. Available at http://digitalcommons.ilr.cornell.edu/chrr/74 on 15 September, 2018.

Organisation for Economic Cooperation and Development. (2008). OECD Annual Report 2008. Organisation for Economic Co-operation and Development. Available at https://www.oecd. org/newsroom/40556222.pdf on 15 September, 2018.

Othman, A. A. E. (2013). Challenges of mega construction projects in developing countries. Organisation, Technology and Management in Construction: An International Journal, 5(1), pp. 730-746.

Othman, A. A. E., Hassan, T. M., \& Pasquire, C. L. (2004). Drivers for dynamic brief development in construction. Engineering, Construction and Architectural Management, 11(4), pp. 248-258.

Othman, A. A. E., \& Mia, B. (2008). Corporate social responsibility for solving the housing problem for the poor in South Africa. Journal of Engineering, Design and Technology, 6(3), pp. 237-257.

Othman, A. A. E., \& Sirbadhoo, N. (2009). An innovative partnership framework for sustainable development of rural areas on 
South Africa: The role of project management firms. Journal of Engineering, Design and Technology, 7(3), pp. 243-263.

Paauwe, J., \& Boon, C. (2009). Strategic HRM: A Critical Review. Routledge, London. ISBN: 9780415462464.

Richardson, S. (2007). What Is a Skill Shortage? National Centre for Vocational Education Research, Adelaide, Australia. Available at https://www.ncver.edu.au/research-and-statistics/ publications/all-publications/what-is-a-skill-shortage on 15 September, 2018.

Rwelamila, P. M. D. (2007). Construction project management education programmes in South Africa- addressing the gap. In: 2nd International Conference World of Construction Project Management, TU Delft, Netherlands.

Ryan, L. (2016). The Most Serious Skill Gap of All. Forbes. Available at https://www.forbes.com/sites/lizryan/2016/08/18/ the-most-dangerous-skills-gap-of-all/\#3637f10e42d3 on 15 September, 2018.

Shah, C., \& Burke, G. (2005). Skills shortages: Concepts, measurement and policy responses. Australian Bulletin of Labour, 31(1), pp. 44-71.
Siriwardena, M., Amaratunga, D., Malalgoda, C., \& Thayaparan, M. (2010). Addressing the Construction Labour Market Skills Mismatch Through Lifelong Learning in Higher Education Institutions. The University of Salford, Available at http://usir. salford.ac.uk/16880/1/paper_162.pdf on 15 September, 2018. Sitek, S. (2012). Bridging The Skill Gap. American Society for Training \& Development, Alexandria.

Sokkar, D. A. A., Elsaay, H. A. I., Othman, A. A. E., \& Agumba, J. N. (2017). Good-to-great concept: A novel approach for addressing the skills gap in architectural design firms in developing countries. In: Proceedings of the 11th Built Environment Conference, Durban, South Africa, 6-8 August, 2017, pp. 37-46, ISBN: 978-0-620-76406-3.

Szymanski, S. (2006). What is the Construction Industry? An Economic Fact Book. The Harry Van Arsdale Jr. Center for Labor Studies Empire State College, New York City.

Ulrich, D., \& Smallwood, N. (2012). What is leadership? In: Mobley, W. H., Wang, Y., \& Li, M. (eds.), Advances in Global Leadership, Vol. 7. Emerald Group Publishing Limited, Bingley, UK, pp. 9-36. 